\title{
Biologian ja epistemologian vastavuoroisuus Bergsonin filosofiassa
}

\author{
LAURI MYLLYMAA
}

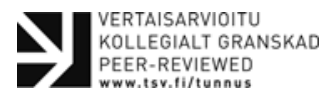

\begin{abstract}
ABSTRAKTI Elämä on nähty merkittävänä aiheena Bergsonin filosofiassa. Elämän filosofinen merkitys Bergsonilla ilmenee selvästi hänen pääteoksessaan L'évolution créatrice (Luova evoluutio, 1907), jossa hän keskittyy inhimillisten tietokykyjen evolutiivisen alkuperän rekonstruointiin ja tieto-opillisiin seurauksiin. Bergsonin mukaan biologia tarjoaa filosofialle tietokykyjen kehitysteoreettisen näkökulman, ja filosofia metafysiikkana täsmentää biologialle sopivaa epistemologiaa. Tässä artikkelissa esittelen Bergsonin filosofisen teorian biologian ja epistemologian vastavuoroisesta suhteesta. Aloitan epistemologian, tieteen ja metafysiikan välisen suhteen selventämisellä Bergsonin teoriassa. Sen jälkeen esittelen, kuinka Bergson näkee tietokykyjen kehittymisen olennaisena osana eläinten yleistä kehityshistoriaa. Analysoimalla eläinkunnan kognitiivisten kykyjen kahta taipumusta, älykkyyttä (intelligence) ja vaistoa (instinct), Bergson kehittää näkemyksen metafysiikasta, jonka avulla on mahdollista selvittää epistemologian ja biologian keskinäistä riippuvuutta ja vastavuoroisuutta. Lopuksi valaisen tätä vastavuoroisuutta Bergsonin analyysilla käsitteellisen tiedon muodostumisesta.
\end{abstract}

Bergsonin filosofia on yli sadan vuoden ajan nähty yleisesti tietynlaisena elämänfilosofiana. Näkemys pätee siinä mielessä, että Bergson piti elämätieteiden roolia välttämättömänä inhimillisen tiedon ja ihmisen tietokykyjen tutkimuksessa. Bergsonin motivaation löytääkseen lukijan tarvitsee ainoastaan tutustua hänen pääteoksensa Lévolution créatrice (Luova evoluutio, 2013/1907) johdantoon. Bergson kirjoittaa, että "tietoteoria ja teoria elämästä näyttäytyvät minulle toisistaan erottamattomina" ${ }^{~}$ (Bergson 2013/1907, ix, kursiivi poistettu) ${ }^{2}$.

Bergsonin mukaan biologinen evoluutio viittaa sekä tiettyyn tapaan käsittää tiedon luon- ne että tiettyyn metafysiikkaan, jotka ovat toisiinsa erottamattomassa yhteydessä (Bergson 2013/1907, 186). Bergson näyttää tavoitelleen pääteoksessaan epistemologian, metafysiikan ja biologian yhteistä kehitysteoriaa. Tämä yhteinen kehitysteoria on Bergsonin strategia ratkaista tiedon luonteeseen ja pätevyyteen liittyviä filosofisia ongelmia. Kuten tulemme näkemään, useat filosofit ovat epäilleet, että ihmisen tietokyvyt tavoittavat tiedon kohteet sellaisinaan. Bergsonin mukaan meillä onkin pätevä syy olettaa, että tietokyvyt ovat evolutiivisesti kehittyneet käytäntöön eivätkä spekulaatioon. (Ks. Bergson 2013/1934, 199.) Täten epistemologia ja metafy- 
siikka näyttäisivät edellyttävän biologista tutkimusta. Biologinen tutkimus kuitenkin käyttää jo olemassa olevia ja saavutettuja järkeilyn muotoja ennalta oletetuista tutkimuskohteista - biologia olettaa tietyn epistemologian ja metafysiikan.

Selkeyden muodostaminen tällaisessa vastavuoroisuudessa saattaa vaikuttaa mahdottomalta, mutta Bergsonin mukaan se on filosofian ominainen tehtävä. Filosofian tarvitsema apu löytyy evoluutiobiologiasta, joka kykenee selittämään vähintään yleisesti tiedon kehitykselliset tekijät. Toisaalta evoluutiobiologia osana systematisoitua inhimillistä tietoa on ehdollista samalla tavalla kuin kaikki muukin tieto. Bergsonin mukaan tietokykyjen tutkimus tarvitsee evoluutiobiologista tutkimusta, mutta evolutiivinen muutos ja elävät olennot eivät sellaisinaan sovellu inhimillisen järkeilyn kohteiksi. Biologia tarvitsee elämän luonteelle eli ajallisuudelle ja luovuudelle soveltuvan ymmärryksen, jotta se voi saada kohteistaan varmaa tietoa.

Tässä artikkelissa analysoin Bergsonin käsitystä epistemologian ja biologian vastavuoroisuudesta. Avaan ensiksi Bergsonin käsitystä filosofian roolista tiedon luonnetta ja alkuperää koskevissa kysymyksissä. Tämän jälkeen esittelen Bergsonin hahmottelemat evoluution oleelliset lainalaisuudet, jotka ovat olleet oleellisia myös kognitiivisten kykyjen evoluutiossa. Seuraavaksi osoitan, kuinka tietoa koskevat kognitiiviset kyvyt jakautuvat Bergsonin käsityksessä kahteen toisistaan poikkeavaan taipumukseen eli älykkyyteen ja vaistoon. Lopuksi osoitan, kuinka selkeämpi ymmärrys ihmisen tietokyvyistä auttavat erityisesti käsitteellistä tietoa koskevien ongelmien ratkaisemisessa.

\section{Epistemologian biologinen näkökulma osana tiedon lähtökohtien metafyysistä selittämistä}

Bergson kirjoittaa, että "tiedon ongelma [...] on yhtä metafyysisen ongelman kanssa ja molemmat ratkeavat kokemuksen avulla" ${ }^{3}$ (Bergson 2013/1907, 179). Mitä nämä ongelmat ovat? Lyhyesti sanottuna tiedon ongelma koskee tiedon pätevyyttä ja metafyysinen ongelma koskee asi- oiden absoluuttisen tietämisen mahdollisuutta. Epistemologia, metafysiikka ja tiede muodostavat yhdessä kokemukseen perustuvan toisiinsa tukeutuvan kehän ja tämän kehän keskipiste voi olla ainoastaan "evoluution empiirinen tutkimus" (l'étude empirique de l'évolution; Bergson 2013/1907, 180). Näiden alojen vastavuoroisuus on tyypillinen empiirinen toisiaan täydentävien todisteiden kehä kohti yhä selvempää varmuutta.

Epistemologian ja biologian vastavuoroisuus liittyy oleellisesti Bergsonin yleiseen filosofiakäsitykseen. Hänen mukaansa filosofia "ei pysty hyväksymään [...] puhtaan intellektualismin muodostamaa [...] metafysiikan ja tieteen välistä suhdetta"4 (Bergson 2013/1907, 195). Oliko Bergson anti-intellektualisti? Bergsonin aikalainen John Dewey (1859-1952) luonnehtii osuvasti 1900-luvun alussa käytettyjä intellektualismin ja antiintellektualismin määritelmiä. Deweyn määritelmän mukaan tietty anti-intellektualismi - johon hän laskee myös itsensä - tarkoittaa tiedon kohteena olevien asioiden selittämistä esimerkiksi biologisen ja sosiologisen tutkimuksen pohjalta käsitteiden loogisen analyysin sijaan, jonka hän näkee intellektualistisena selittämisenä. Deweyn mukaan tiedon luonteen tutkiminen tarvitsee siten tiedon mahdollistavien tekijöiden tutkimista. (Dewey 1910, 478-479.) Bergsonin filosofiaa voidaan näin ollen luonnehtia Deweyn määritelmän mukaan anti-intellektualistiseksi, koska Bergson tavoitteli tiedon kehittymisen ja alkulähteiden tutkimista.

Bergsonin mukaan filosofit ovat yleisesti ymmärtäneet inhimillisen tiedon jakautuvan kahteen osaan: välilliseen ja symboliseen eli suhteelliseen tietoon ja välittömään eli absoluuttiseen tietoon (Bergson 2013/1934, 177-178). Edellisen menetelmänä on nähty analyysi ja jälkimmäisen menetelmänä intuitio tai sympatia (Bergson 2013/1934, 181). Sympatialla on tavoiteltu ilmiöiden ymmärtämistä sellaisenaan, absoluuttisesti, johon käsitteellinen ajattelu ei kykene (ks. Bergson 2013/1934, 196-200). Bergsonin näkemys absoluuttisesta tiedosta eroaa useista 1800-luvulla esitetyistä tiedon luonnetta koskevista tutkimuksista, jotka tyypillisesti kielsivät metafysiikan eli absoluuttisen tiedon mahdollisuuden (ks. Spencer 2009/1862, 69). 
Kuten totesin, absoluuttinen tieto on yleensä määritelty tiedoksi, joka ymmärtää kohteensa sellaisenaan, ilman sitä ehdollistavia tai suhteellistavia tekijöitä. René Descartesille (1596-1650) tieto on joko absoluuttista (absolutum) tai suhteellista (respectivum) kognition tavoitteiden mukaan (AT X, 381, ks. 381-387; Descartes 2015, 56, ks. 55-59). Tieto on absoluuttista, kun sen kohdetta ajatellaan sellaisenaan ja suhteellista, kun sitä ajatellaan toisten asioiden kautta tai niitä varten. Esimerkiksi Étienne Bonnot de Condillac (17141780) ja Immanuel Kant (1724-1804) määrittelivät 1700-luvulla jaon absoluuttiseen ja suhteelliseen pitkälti samalla tavalla kuin Descartes (Condillac 2014/1749, 146; A234/B380-A236/B382).

Sama käsitys tiedon jakautumisesta absoluuttiseen ja suhteelliseen tietoon jatkui useissa 1800-luvun filosofisissa töissä, jotka näyttäytyivät Bergsonin filosofisukupolvelle tärkeänä teoreettisena taustana. Merkittävimpiä absoluuttisen tiedon kriitikkoja 1800-luvulla olivat William Hamilton (1788-1856), Auguste Comte (1798-1857), John Stuart Mill (1806-1873) ja Herbert Spencer (1820-1903). Esimerkiksi Mill kuvaa hänen jakamaansa Comten näkemystä näin: "Meillä on tietoa ainoastaan ilmiöistä ja tietomme ilmiöistä on suhteellista eikä absoluuttista. Emme tiedä minkään tosiseikan olemusta tai tuottumisen tapaa [mode of production] vaan ainoastaan sen suhteet toisiin tosiseikkoihin niiden peräkkäisyyden tai samankaltaisuuden mukaisesti." (Mill 1887, 7, kursiivi muutettu; ks. Comte 1844, 13-14.) Hamilton ja Spencer jakoivat saman näkemyksen (Hamilton 1860, 136-137; Spencer 2009/1862, 69).

Itse asiassa Spencer ilmaisi absoluuttisen tiedon mahdottomuuden tavalla, joka antaa meille luonnollisen siirtymän takaisin Bergsoniin. Spencerin mukaan "[t]odistus, että kognitiomme eivät ole eivätkä koskaan voi olla absoluuttisia, on saavutettavissa joko ajattelun tuotoksen tai ajattelun prosessin analyysilla"6 (Spencer 2009/1862, 69). Jos absoluuttisen tiedon mahdottomuus voidaan todistaa ihmisen ajattelukykyjen ja niiden tuotosten analyysilla, eikö filosofin tule myös ottaa huomioon, että ajattelun tuotosten ja prosessien toisenlainen tutkiminen voi puoltaa myös Spencerin mainitseman analyysin vastaisia tuloksia?
Spencerin johtopäätökset nimittäin koskivat käsitteellistä tietoa. Käsitteet ovat kuitenkin älykkyyden tuotteita tai välineitä, ja älykkyydellä on selvästi erottuvat tavat käsittää kohteensa. Bergsonin mukaan käsitteellisen ajattelun eli älykkyyden suhteellisuus määrittyy sen hyötynäkökulmasta käsin. Jotta absoluuttinen eli riippumaton tieto olisi mahdollista, epistemologian perusta on irrotettava älykkyyden tuotteista eli käsitteistä, mikä samalla tarkoittaa irrottautumista hyötynäkökulmaisesta suhteellisuudesta. Samalla tiedon suhteellisuus käsitetään oikein, eikä se ole enää rajoittunutta tai puutteellista tietoa vaan toinen osa inhimillisen tietokyvyn kokonaisuutta. (Ks. Bergson 2013/1934, 199.) Tätä tehtävää varten Bergson tarvitsee yleiskäsityksen ihmisen koko kognitiivisesta toiminnasta ja sen kehittymisestä. Bergson jatkaa selvästi filosofian perimmäisten ongelmakohtien ratkaisemista, mutta hänen ratkaisunsa ovat uudenlaiset. Tämä uutuus ammentaa ennen kaikkea evoluutiobiologiasta. Siirrymme seuraavaksi Bergsonin tulkintaan biologisen evoluution yleisimmistä lainmukaisuuksista.

\section{Bergsonin näkemys evoluution oleellisimmista lainmukaisuuksista}

Ihmisen tietokyvyt ovat Bergsonin mukaan samojen evolutiivisten tekijöiden tulos kuin muutkin evoluution myötä kehittyneet ilmiöt. Siksi tietokykyjen kehittymisen ymmärtäminen vaatii yleiskuvaa evoluution merkittävimmistä lainmukaisuuksista (ks. Bergson 2013/1907, 106). Evoluution lainmukaisuuksien käsittämiseksi Bergson loi "elämän hyöyn"7 (élan vital) mielikuvan. Kutsun elämän hyökyä tässä asiayhteydessä mielikuvaksi, koska kyse ei ole käsitteestä (ks. François 2010a, 97-98). Elämän hyöyn alkuperä lienee André Lalanden (1867-1964) väitöskirjassa La dissolution opposée à l'évolution dans les sciences physiques et morales (Dissoluutio evoluution vastakohtana fysikaalisissa ja käyttäytymistieteissä ${ }^{8}$, 1899; ks. Scharfstein 1943, 81; Sinclair 2020, 213). ${ }^{9}$ Tulkintani mukaan elämän hyöky on oleellinen osa aiemmin esittelemääni epistemologian ja biologian välistä erottamatonta yhteyttä ja se va- 
lottaa Bergsonin filosofisia tavoitteita ja motivaatioita. Bergsonin mukaan elämän hyöky "ei missään nimessä ole tyylillä koristelua, eikä se mielikuvalla pyri peittämään tietämättömyyttämme [evoluution] perustavanlaatuisesta kausaalisuudesta"10 (Bergson 1972, 1526). Elämän hyöky oli Bergsonin mukaan paras tapa mieltää evoluutio, koska "ei ole olemassa fysikaalisesta todellisuudesta lainattua mielikuvaa, mikä kykenisi antamaan meille siitä likimääräisempää ajatusta"11 (Bergson 2013/1907, 258).

Elämän hyöystä voidaan erottaa sen kaksi merkittävintä luonteenpiirrettä. Elämän hyöky on lajinsisäisen vaihtelun perimmäinen syy ja "hypoteesi eliöiden yhteisestä alkuperästä" (l'hypothèse d'un élan commun; Bergson 2013/1907, 88). Se on lisäksi tästä yhteisestä alkuperästä juontuvien "taipumusten epävakaa tasapainotila" (un équilibre instable de tendances; Bergson 2013/1907, 99). Tähän taipumusten epävakaaseen tasapainotilaan liittyy kolme tekijää. Taipumukset syntyvät eliöiden kehityslinjojen eriytymisellä (divergence). Yhteisestä kantamuodosta eriytyneitä kehityslinjoja luonnehtii sekä niiden yhteensopimattomuus (incommensurabilité) että toisiaan hyödyntävä täydentävyys (complémentarité).

Eriytyminen ja yhteensopimattomuus tarkoittavat Bergsonin mukaan sitä, että eliöpopulaatiossa syntyy kaksi eri sopeutumisen aiheuttamaa kehityssuuntaa, jotka alkavat voimistua eli eriytyä toisistaan. Molemmat kehityssuunnat korostavat niitä yhteisen lähtökohdan piirteitä, jotka korostuessaan joutuvat luopumaan joistain muista niiden yhteisessä kantamuodossa idullaan olleista ominaisuuksista, jotka eivät voi korostua toisten ominaisuuksien voimistuessa. (Bergson 2013/1907, 53; ks. Leslie ym. 2017; Roff \& Fairbairn 2007.) Täydentävyys tarkoittaa Bergsonin mukaan sitä, että tiettyjä piirteitä korostavat lajit tai ominaisuudet kykenevät hyödyntämään ja edistämään toistensa menestystä (Bergson 2013/1907, 117). Nämä kaksi taipumusta esiintyvät kaikkialla evoluution taitekohdissa.

Luonnonhistoriallisesti ja evolutiivisen muutoksen merkittävimpänä esimerkkinä näistä kahdesta taipumuksesta Bergson käyttää kasvien (erityisesti Embryopsida) ja eläinten (erityisesti Meta- zoa) yhteisestä aitotumallisesta kantamuodosta eriytymistä. Kasvien ja eläinten yhteen sopimattomat tavat elää ovat toisiaan täydentäen mahdollistaneet ympärillämme nähtävän eliökehän yhdessä sienten ja erilaisten mikro-organismien kuten bakteerien ja arkeonien kanssa. Kasvien ja eläinten yhteensopimattomuus esiintyy niiden tavoissa kerätä hiiltä ja energiaa. Kasvit keräävät hiilen epäorgaanisesta lähteestä eli ilmakehästä ja tuottavat energiansa itse fotosynteesin avulla auringonvalosta. Ne ovat siis fotoautotrofeja. Eläimet keräävät sekä hiilen että energian syömällä toisia eliöitä. Ne ovat puolestaan kemoheterotrofeja. (Ks. Bergson 2013/1907, 107-109, 117.)

Eläinten tapa kerätä ravintoa ja energiaa ovat urauttaneet ne kehittymään liikkuvaan elämäntapaan, johon kuuluvat oleellisesti hermosto, aistinelimet ja lihaksisto. Kaksikylkisten (Bilateria) eläinten kahdessa pääjaksossa eli niveljalkaisissa (Arthropoda) ja selkäjänteisissä (Chordata) löytyvät kaksi lahkoa eli pistiäiset (Hymenoptera) ja kädelliset (Primates), jotka ovat toistensa kehityshistorioista todella etäisiä, mutta joiden keskushermostoon on kehittynyt tehokkaat aivot. Bergsonin mukaan nämä kaksi kognitiivista kehityslinjaa tarjoavat tärkeää tietoa erilaisten tietokykyjen luonteenpiirteistä.

Bergsonin mukaan yhteensopimattomuus ja vastavuoroisuus tai täydentävyys esiintyvät yhtä lailla eläinkunnan kognitiivisten taipumusten kehityksessä. Bergsonin mukaan eläinkunnassa esiintyy kaksi kognitiivista taipumusta, joita hän kutsuu aikakaudelleen tyypillisesti älykkyydeksi (intelligence) ja vaistoksi (instinct). Kognitiivisilta ominaisuuksiltaan älykkyys ja vaisto ovat keskenään yhteensopimattomia tietokykyjä. Ne ovat kehittyessään joutuneet luopumaan yhteisessä alkuperässään idullaan olleista ominaisuuksista. Molemmat kuitenkin toteuttavat eläimen kognitiivisen toimintaperiaatteen omilla, yhteensopimattomilla tavoillaan. Tämä toimintaperiaate on eläimen kyky toimia havaitsemassaan ympäristössä (Bergson 2013/1907, 136-137, 142-144, 168169). Nimenomaan yhteensopimattomuutensa vuoksi älykkyys ja vaisto kykenevät myös täydentämään toisiaan, kuten hieman myöhemmin tulemme näkemään. Käyn molempien taipumusten 
luonteenpiirteet tiiviisti läpi, jonka jälkeen näytän, kuinka Bergson käsittää niiden epistemologisen merkityksen.

\section{Älykkyyden spatiaaliset toimintaperiaatteet}

Bergsonin mukaan älykkyys merkitsee ennen kaikkea etäisyyttä mielteen ja suoritettavan toiminnan välillä. Tällä etäisyydellä hän tarkoittaa yksilön kykyä pidättäytyä välittömästä reaktiosta harkinnan avulla. Harkinnan aikana yksilö kykenee valikoimaan sopivan vastauksen vastaanotettuun ärsykkeeseen. (Bergson 2013/1907, 145.) Valikointi tapahtuu mielteiden avulla. Mieltäminen on luonteeltaan spatiaalista, mikä tekee havaintokohteista pysyviä ja mahdollistaa niiden erittelyn (Bergson 2013/1907, 154-156, 190; 2013/1889, 177). Havaintokohteiden pysyvyys ja erottelu mahdollistavat niiden analysoinnin ja syntetisoinnin. Kuten Bergson toteaa, älykkyyttä luonnehtii sen rajaton kyky luoda sekä sääntöjä, joiden avulla se kykenee jaottelemaan asioita, että järjestelmiä, joiden avulla se kykenee yhdistämään jaottelemiaan asioita (Bergson 2013/1907, 158, ks. 176). Lyhyesti sanottuna älykkyyden ensimmäinen ja merkittävin luonteenpiirre on spatiaalinen mieltäminen, ja tämä luonteenpiirre on ylivoimaisen korostunut ihmisessä.

Mielteiden spatiaalisuus ja niiden analyysi ja synteesi ovat puolestaan oleellisessa yhteydessä havaintokohteiden muokkaamisen ja työvälineiden valmistamisen kanssa (Bergson 2013/1907, 141). Havaintokohteiden muokkaaminen ja työvälineiden valmistaminen ovat muodostaneet älykkyydelle kaksi kausaalikognition mallia: mekanismin ja finalismin (Bergson 2013/1907, 164-165). Mekanismi tarkoittaa sitä, että älykkyys erottaa tietystä asiasta sitä edeltäviä asioita, jotka selittävät sen olemassaolon. Finalismi tarkoittaa sitä, että älykkyys erottaa tietystä asiasta sen mitä varten se on olemassa. Ennen kirveen valmistamista minun on tiedettävä kirveen käyttötarkoitus eli määrittelen kirveen käsitteen finalistisesti. Kirveen valmistamiseksi minun on tiedettävä sen osatekijät eli varsi ja kirveenterä ja niiden valmistusvaiheet, joiden etenemisjärjestyksen ja keski- näiset suhteet määrittelen mekanistisesti. Nämä Bergsonin erittelemät älykkyyden yleispiirteet näyttävät olevan samansuuntaisia monien nykytieteellisten tutkimusten kanssa. ${ }^{12}$

Ihmisessä spatiaalisen mieltämisen luonteenpiirre näkyy puhtaimmillaan logiikassa, geometriassa ja algebrassa. Kuten Bergson sanoo, ”[k] aikki älykkyytemme toiminta pyrkii kohti geometriaa" ${ }^{13}$ (Bergson 2013/1907, 211, ks. 217). Geometrialla Bergson tässä asiayhteydessä tarkoittaa älykkyyden kykyä puhtaaseen spatiaalisuuteen ja suhteiden käsittämiseen, joita edellä erittelin. Kaksi spatiaalisesti ja suhteellisesti toimivan älykkyyden toimintaperiaatetta ovat deduktio ja induktio, joiden Bergsonin esittämät perusperiaatteet käyn seuraavaksi lyhyesti läpi.

Jos tiedän, että kolmion kolme kulmaa ovat yhtä suuria, voin deduktiivisesti päätellä, että kolmion sivujen pituudet ovat niin ikään yhtä suuria. Tämä on välttämätön geometrinen tosiasia, joka ei vaadi sen enempää kokemukseen perustuvaa tietoa. Tällainen tosiasia on niin tosi kuin asia voi olla. Tällainen järkeily on kuitenkin järkeilyä valmiiksi saavutetuilla asioilla. Looginen päättely johtaa premisseistä johtopäätöksen, joka oli jo annettuna premisseissä. Johtopäätös on vain premisseissä valmiina olleen tiedon selvä ilmaisu. Tämä tosiasia muuttuu selkeäksi, kun ajatellaan sen kontrastia todellisuudessa ilmenevään laadulliseen muutokseen. Päättely edellyttää, että premissit pysyvät samoina koko päättelyprosessin ajan. Lisäksi kahdesta samasta premissistä on aina odotettavissa sama johtopäätös. Päättely lakkaa olemasta pätevä, jos premissien ilmaisemat asiat ovat luonteeltaan muuttuvia. Asioiden muuttuessa deduktion tulee tehdä niistä uusi yleistys, jotta se saisi muodostettua edes hetkeksi pätevät premissit. Deduktio joutuu siis tukeutumaan induktioon, jotta se saisi yleistämisen avulla päivitettyä riittävän kattavat ja yleiset premissit, joiden pohjalta se voi suorittaa deduktiivisen päättelyn. (Ks. Bergson 2013/1907, 212-214.)

Bergsonin mukaan induktio ja deduktio ovat toisiinsa tiiviisti yhteydessä myös induktiivisen päättelyn näkökulmasta. Induktiivisella päättelyllä voidaan esimerkiksi väittää, että hellan kuumuus saa veden kiehumaan kattilassa, koska aina 
kun asetan vesikattilan hellalle ja käynnistän hellan, vesi alkaa hetken kuluttua kiehua. En tarvitse tällaiseen pätevään induktioon muuta kuin oman kokemukseni veden keittämisen tekijöistä, eli hellasta, kattilasta ja vedestä ja niiden välisistä suhteista. Tarvitaan tuskin suurempaa järkeilyä, että voidaan todeta samojen seurausten johtuvat samoista asiantiloista. Uskomukset syiden ja seurausten olemassaolosta ja syy-seuraussuhteista ovat nimenomaan uskomuksia. Bergsonin mukaan tällainen uskomus vaatii oletuksen, että on olemassa muuttumattomia ja toisiaan identtisesti vastaavia asioita, jotka voidaan eristää niitä ympäröivästä todellisuudesta. Tällainen oletus on kuitenkin täysin luonnollinen, koska älyllinen järkeily perustuu sen itse luomille muuttumattomille ja identtisille mielteille. Älykkyys joutuu olettamaan, että sen luomukset ovat kuin ikuisia ja muuttumattomia. Arkielämässä tällaisesta käytännön toimintaan tarkoitetusta päättelystä ei ole mitään haittaa. (Ks. Bergson 2013/1907, 214-217.)

Metafysiikalle älykkyyden luonnollinen taipumus käsittää asiat muuttumattomina ja identtisinä ei kelpaa, koska sitä ei kiinnosta älykkyyden tehokkuus ja käytännöllisyys vaan asioiden luonteet sellaisinaan. Metafysiikalle ja epistemologialle oleellista on ottaa selvää tämän eristämisen tarkoitusperistä ja sen vaikutuksista asioiden ymmärtämiselle. Asioiden luonteiden ymmärtämiselle tällaisella käytännöllisellä toimintaperiaatteella on vakavia seurauksia, jotka haittaavat tiedon luonnetta koskevaa tutkimusta. Metafyysiset ongelmat siirtyvätkin tieto-opillisiin ongelmiin, kuten Bergson on osoittanut (Bergson 2013/1889, vii; 2013/1934, 8-11, 22, 57-59, 194, 196).

\section{Vaiston organisoivat toimintaperiaatteet}

Elävien eli lähtökohtaisesti muuttuvien ja kehittyvien olentojen ymmärtämiseksi tarvitaan Bergsonin mukaan vaistomaista ei-spatiaalista ajattelua, joka voidaan toimintaperiaatteeltaan jossain määrin samastaa elämän itsensä kanssa. Metafysiikan ja epistemologian on kohdistettava huomionsa tähän tietokykyyn, jotta ne voisivat löytää itselleen asianmukaisen perustan ja siten myös tarjota biologialle oikean tavan ymmärtää elävää luontoa. (Bergson 2013/1907, 166.) Bergsonin mukaan vaisto on kognitiivinen taipumus, jonka modus operandi on sen modus vivendi sen kognitiivinen toimintatapa on yhtä kuin sen tapa elää. Vaisto eroaa täten älykkyydestä siinä, että älykkyyden toimintaperiaatteeseen kuuluu spatiaalisten mielteiden käyttäminen välillisinä kognitiivisina instrumentteina, kun taas vaisto ei käytä samanlaisia välillisiä mielteitä.

Bergsonin mukaan vaistomaista käyttäytymistä on lähestytty kahdesta eri näkökulmasta. Ensimmäinen näkökulma on käsittänyt vaiston joko vain refleksiivisenä reaktiona ja sen monimutkaistumisena tai automatisoituneena tottumuksena. Toinen näkökulma on käsittänyt vaiston omalaatuisena kognition muotona, joka on kehittynyt rinnan älykkyyden kanssa. Bergsonin mukaan näillä kahdella näkökulmalla on omat seurauksensa. Jos vaisto ymmärretään ensimmäisen näkökulman mukaan, se tarkoittaa vaiston käsittämistä vain älykkyydelle itselleen luontevien käyttäytymismallien eli refleksin ja tottumuksen mukaan. Jos vaisto ymmärretään jälkimmäisen näkökulman mukaan, älykkyydestä tulee sokea vaistomaiselle kognitiolle ja sen tieteellinen tutkimus muuttuu vaikeaksi. Täten ei liene ihme, että vaisto on yleisesti nähty joko refleksiivisenä tai tottumuksellisena käytöksenä. (Ks. Bergson 2013/1907, 175; ks. Darwin 2016, 179-180, 185.) Älykkyyden sokeus koskien vaistoa johtuu Bergsonin mukaan samoista evolutiivisista yhteensopimattomuuteen liittyvistä syistä, jotka aiemmin lyhyesti esittelin.

Bergson jakaa edellä mainituista kahdesta näkökulmasta jälkimmäisen. Hän ei ollut ainoa tämän näkökulman kannattaja, vaan esimerkiksi myös Charles Darwin (1809-1882) kannatti sitä. Ensimmäisen näkökulman kannattajiin 1800-luvun loppuvaiheilla lukeutui erityisesti Spencer, minkä Darwin oli pistänyt merkille (ks. Darwin 2009/1871, 37). Esittelen pari oleellista huomiota vaiston käsitehistoriasta, koska se on aiheuttanut vakavia tieteelliseen tutkimukseen vaikuttaneita kiistoja eri tieteilijöiden ja tieteellisten tutkimussuuntien välillä. Tämä historiallinen taustoitus tarjoaa meille yleiskuvan vaistomaisen käyttäy- 
tymisen aiheuttavan kognition vaikeasti ymmärrettävästä luonteesta. Vaistosta käydyt tieteelliset kiistat ovat antaneet käsitteelle epäselvän ja jopa epätieteellisen leiman, jotka sekä vaiston käsitettä tutkivan että yleisesti koko aatehistoriallisen tutkimuksen on hyvä tunnistaa.

Keskustelu vaistoista oli kiivasta 1870-luvulta 1920-luvulle. Väittely sai alkunsa useiden biologien kuten Darwinin, Alexander Bainin (18181903), Spencerin, Albert Lemoinen (1824-1874) ja Léon Dumontin (1837-1877) pyrkimyksissä määritellä vaistomaista käyttäytymistä ja sen tieteellistä tutkimusta (ks. Lévêque 1876). ${ }^{14}$ Kiista päättyi behavioristisen psykologian saavuttaessa tieteenalansa hallitsevan aseman. Esimerkiksi Zing-Yang Kuo (1898-1970) hyökkäsi voimakkaasti vaiston käsitettä vastaan artikkelissaan "Giving up Instincts in Psychology" ("Vaistoista luopuminen psykologiassa", 1921; ks. Beach 1955, 403-404). Itse asiassa L'évolution créatrice saattoi jopa kiihdyttää aikansa kiistoja, sillä vuonna 1910 British Journal of Psychology omisti kolmannen vuosikertansa kolmannen julkaisun vaiston teemanumerolle, jonka artikkeleista ainakin Carr (1910) keskittyi Bergsonin teorian tulkitsemiseen.

Vaistomaisen käyttäytymisen tai kognition tutkimus ei kuitenkaan kokonaan kadonnut, vaikka puhe vaistoista katosi tieteellisten kiistojen keskiöstä tieteen hiljaisille laitamille. Vaiston käsitteen käytön vaimennuttua 1930-luvulla Konrad Lorenz (1903-1989) ja Nikolaas Tinbergen (19071988) kehittivät uuden eläinten käyttäytymiseen keskittyvän biologisen tieteen, jonka he nimesivät "etologiaksi". Etologia käsitteellisti uudelleen käyttäytymismallit, jotka ennen oli ymmärretty vaistomaisena käyttäytymisenä. Vaisto käsitteellistettiin uudelleen esimerkiksi "sisäisenä vapautusmekanismina" (angeborener Auslöse-Mechanismus; ks. Brigandt 2005, 590-591; Richards 1974, 113; Ronacher 2019, 34).

Kuten edellä esittelemistäni teorioista voidaan päätellä, Bergsonin elinaikana luodut tieteelliset teoriat ja niiden väliset kiistat osoittavat, että vaistomaista kognitiota ei ole luonteeltaan juurikaan - jos lainkaan - erotettu eläinten älyllisestä käyttäytymisestä. Siirrytään nyt Bergsonin vaistomaisen kognition käsittelyyn. Erotan Bergsonin vaiston käsityksestä kaksi eri toimintaperiaatetta: yliyksilöllisen organisoitumisperiaatteen ja lajienvälisen käyttäytymisperiaatteen.

Bergsonin mukaan vaisto on yksilönkehityksen "jatke" (prolongation) tai "tuotos" (achèvement; Bergson 2013/1907, 140; ks. 2013/1932, 123). Tällä hän tarkoittaa, että havaittu vaistomainen käytös juontuu yksilönkehityksestä samalla tavalla kuin muutkin yksilön elimet. Voitaisiin jopa sanoa, että yksilönkehityksellisestä näkökulmasta vaisto on "kognitiivinen elin". Itse asiassa vaisto jakaa saman järjestäytymisen taipumuksen kuin monisoluisen eliön solut tai tiettyjen hyönteisten aitososiaalisuus. Bergsonin sanoin: "Mehiläisen elävöittävä vaisto yhdistyy siten kykyyn, joka elävöittää solun tai on tämän kyvyn jatke. Näiden kaltaisissa äärimmäisissä tapauksissa vaisto on yhteneväinen organisoitumisen kanssa." ${ }^{15}$ (Bergson 2013/1907, 167.) Bergsonille vaisto näyttäytyy korostetuimpana useissa pistiäisiin (Hymenopte$r a)$ kuuluvien sukujen kuten kaivaja-ampiaisten (Sphex) ja hunajamehiläisten (Apidae) lajeissa. Siksi hän tarkastelee erityisesti näitä lajeja.

Bergson näkee solujen välisessä käyttäytymisessä ja mehiläisten (Apidae) välisessä käyttäytymisessä hänen argumenttiaan tukevan analogian: molemmissa tapauksissa ykseys - oli se sitten tsygootti tai häälentonsa päättänyt kuningatar - jakautuu tai eriytyy moninaisuudeksi säilyttämällä samalla ykseytensä. Tsygootti jakautuu ensin eriytymättömäksi soluryppääksi eli morulaksi, jonka jälkeen siihen alkaa syntyä rakenteellisia eroja, jotka lopulta kehittyvät tietyn ruumiinrakenteen mukaisesti eri elimiksi. Tarhamehiläiskuningatar (Apis mellifera) alkaa munia työläisiä, kuningattaria ja kuhnureita, joilla kaikilla on ennalta määrätty tehtävänsä yhdyskunnassaan. Vaiston ykseyteen pyrkivä toiminta on Bergsonin mukaan koordinoivaa, organisoivaa toimintaa.

Tämä vaiston organisoiva luonteenpiirre ei sovi yhteen älykkyyden luonteenpiirteiden kanssa, joiden tehtävänä on analysoida ja syntetisoida muttei organisoida. Monisoluisen eliön yksilönkehityksen ja aitososiaalisen eliöyhdyskunnan jakautumisprosessit jakavat samankaltaisen kognitiivisen kyvyn, sikäli kun kummassakaan tapauksessa voidaan puhua kognitiosta. Näissä tapa- 
uksissa ei ainakaan ole kyse elottoman luonnon prosesseista vaan elävien olentojen käyttäytymisestä, ja elävän olennon käyttäytyminen johtuu aina vähintään jonkinasteisesta tietoisuudesta ja kokonaisuuden eri osien välisestä koherentista signaloinnista. Bergsonin mukaan näyttää siltä kuin jokainen kokonaisuudesta eriytynyt osatekijä, oli se sitten solu tai mehiläinen, kantaisi mukanaan kokonaisuutta kuin yhteisesti jaettuna "muistina", "muistaen" vain ne "muistot", joita se tarvitsee. (Bergson 2013/1907, 167-168.)

Nykypäivän näkökulmasta voitaisiin sanoa, että eliön erikoistuneiden solujen tiedetään ilmaisevan vain sille välttämättömiä geenejä ja geenien verkostoja. Sukusoluja ja punasoluja lukuun ottamatta kaikki eliön solut sen yksilökehityksen lähtölaukauksesta eli tsygootista aikuisen yksilön valmiiksi kehittyneisiin kudoksiin jakavat identtisen genomin, jos yksilön elinkaaren aikana tapahtuvia mutaatioita ei oteta huomioon. Samaten mehiläispesän kastit ilmaisevat niitä käyttäytymismalleja, joita niiden tehtävänä on toteuttaa, vaikka työläiset ja kuningattaret ovat toistensa siskoja (kuhnurit kehittyvät äitinsä hedelmöittämättömistä sukusoluista). Nämä kaksi organisoitumista jakavat siten analogian, jonka mukaan organisaatio tarkoittaa ykseyttä, joka kykenee eriytymään keskinäisesti koordinoituihin osiin. Lyhyesti sanottuna sekä solut että aitososiaaliset hyönteiset jakavat yliyksilöllisen organisoitumisperiaatteen.

Tästä vaiston organisoivasta luonteenpiirteestä Bergson etenee vaiston seuraavaan luonteenpiirteeseen. Vaiston yliyksilöllinen organisoiva taipumus ei rajoitu vain soluihin ja aitososiaalisiin hyönteisiin. Sama ilmiö on havaittavissa yhtäältä biologisessa yhteistoiminnassa eli mutualismissa kuten tiettyjen orkideoiden ja kärpästen mutualismissa ja toisaalta loisinnassa, jossa yksi eliö hyödyntää toista eliötä sen kustannuksella. Loisinta on erityisen selvästi nähtävillä tiettyjen parasitoidisten pistiäisten kuten kaivaja-ampiaisten (Sphex) tapauksessa, missä ne "sympatisoivat" uhriaan, kun ne etsivät tästä kohtaa, jota pistämällä uhri lamaantuu muttei kuole. Bergson kutsuukin tätä vaiston luonteenpiirrettä "sympatiaksi". (Bergson 2013/1907, 168, 171, 174-175, 177.) Siten mutualismissa tai loisinnassa näkyvät lajienvälinen käyttäytymisperiaate.

Vaistomaisen kognition luonteenpiirteet ovat Bergsonille selvimmin havaittavissa tiettyjen hyönteisten käyttäytymisessä, mutta samoista periaatteista on viitteitä myös ihmisen kognitiivisessa ja sosiaalisessa käyttäytymisessä. Samankaltainen sympatia on nähtävissä siinä mitä sympatialla ihmisten välillä yleensä tarkoitetaan. Sosiaalisuus ja vuorovaikutus ihmisten välillä nojaavat merkittävästi yksilöiden toistensa kanssa jakamaan myötätuntoon. Bergsonin mukaan myötätunto nimenomaan mahdollistaa tietoisuuksien "yhteenkietoutumisen" (interpénétration), jota hän kuvailee "psykologisena endosmoosina" (endosmose psychologique; Bergson 2013/1934, 28). Tietoisuuksien välinen yhteenkietoutuminen voi hyvinkin juontua Bergsonin kuvailemasta vaistomaisesta kognitiosta, jota on toisessa asiayhteydessä kutsuttu myös "vuorovaikutusvaistoksi" (interactional instinct; ks. Lee ym. 2009, 6, 151-153). Sivuutan tässä artikkelissa nämä tiedon välittämiseen liittyvät seikat ja jatkan vaistomaisen kognition roolin selventämistä yhdessä älyllisen kognitiivisen taipumuksen kanssa yksilöllisessä ajattelussa. On joka tapauksessa hyvä pitää mielessä, että Bergsonilla nämä biologiset, sosiaaliset ja yksilön kognitiiviset organisoitumisperiaatteet ovat keskenään analogiset.

\section{Älykkyys ja vaisto kykenevät täydentämään toisiaan}

Bergsonin ydinajatus näyttää olevan, että ihminen kykenee itsetietoisella, oppivalla ponnistelulla korostamaan heikkoa vaistomaista kognitiotaan ja täyttämään niitä ajattelunsa puutteita, jotka ovat älykkyyden korostuessa syntyneet. Täsmennän tässä vaiheessa, että Bergsonin tarkoituksena ei ollut tehdä filosofeista yksinomaan vaistoon tukeutuvia ajattelijoita. Lainaan Bergsonilta lyhyen katkelman, jossa hän vastaa matemaatikko Émile Borelin (1871-1956) häneen kohdistamaan kritiikkiin tiivistämällä vaistoon liittyvät filosofiset tavoitteensa: 
En ole missään kohdassa olettanut, että "älykkyys" pitäisi "korvata jollain toisella asialla" tai suosia vaistoa sen kustannuksella. Olen yksinkertaisesti yrittänyt osoittaa, että kun poistutaan matemaattisten ja fysikaalisten kohteiden alueelta ja siirrytään elämän ja tietoisuuden alueelle, on hyödynnettävä tiettyä elämän tajuamista, joka eroaa puhtaasta ymmärryksestä, ja jonka alkuperänä on sama elämän sysäys kuin vaistolla - joskin vaisto tarkalleen ottaen onkin täysin toinen asia. Tämä elämän tajuaminen tarkoittaa vain tietoisuuden syventymistä, kun se etsii tietyllä itseensä kiertymisellä asettumista takaisin luonnon suuntaan. Se on omanlaisensa kokemus, yhtä vanha kuin ihmiskunta, mutta josta filosofia ei ole ammentanut läheskään kaikkea mitä siitä voitaisiin ammentaa. (Bergson 1908, 30.) ${ }^{16}$

Bergson ei varsinaisesti väitä, että ihminen voisi ajatella vaistomaisesti. Hän ennemminkin väittää, että ihmisessä on idullaan sellainen ajattelun luonteenpiirre, jota voidaan korostuneempana havaita muiden eläinten käyttäytymismalleissa. Yksinkertaisuuden ja selkeyden vuoksi jatkan tämän kognitiivisen taipumuksen kutsumista vaistoksi. Filosofisesti tämä on merkittävää siitä syystä, että tällaisella älyllisellä ponnistuksella tietoisuus voi yhdistää pitkälti älykkyyden toimintaperiaatteen määrittämä inhimillinen ajattelu vaistomaisen toimintaperiaatteen kanssa. Filosofisella ajattelulla on mahdollisuus saattaa älykkyyden modus operandi ja vaiston modus vivendi yhteen.

Kiteytän edellä erittelemäni Bergsonin älyllisen ja vaistomaisen kognition luonteenpiirteet seuraavasti: älykkyys analysoi ja syntetisoi välillisellä, suhteellisella ajattelulla ja vaisto organisoi ja sympatisoi välittömällä ajattelulla (vrt. Bergson 2013/1907, 149). Organisoiva ja sympatisoiva välitön ajattelu on Bergsonille yhtä kuin absoluuttinen tieto. Käsittelen tästä kahtalaisuudesta kahta toisiinsa kietoutuvaa epistemologista aihetta, jotka havainnollistavat Bergsonin näkemystä epistemologian oleellisesta riippuvuudesta ihmisen tietokykyjen biologisesta ja siten evoluutiopsykologisesta perustasta. Aloitan käsittelemällä hypoteettisia ja kategorisia arvostelmia, jonka jälkeen selvennän Bergsonin käsitteiden merkityk- sen muodostumisen teoriaa.

Bergson huomauttaa, että filosofit ovat yleensä jakaneet tiedon kahteen osatekijään: muotoon ja aineeseen (Bergson 2013/1907, 149). Tällainen tietoon liittyvä hylomorfismi on selvimmin näkyvissä Kantilla (ks. Bergson 2013/1907, 205-7). Kantille aine on havaintoainesta, jonka alkuperänä on todellisuus, jota tilan ja ajan intuitiot (saks. Anschauung; lat. intuitio) ensin jäsentävät ja jotka ymmärrys (saks. Verstand; lat. intellectus) ja järki (saks. Vernunft; lat. ratio) lopulta systematisoivat. Intuitiot sekä ymmärryksen ja järjen käsitteet antavat muodon havaitulle aineelle. Kantin sanojen mukaan aine on substantia phenomenon eli kaiken havaittavan aineksen substanssi, jolle tämä toinen, formaali "substanssi" antaa muodon. (A277/ B333, ks. A266/B322-A268/B324.)

Mitä tämä toinen substanssi sitten on? Kant esitti selvästi sen toimintaperiaatteet kokemusta jäsentävinä kahtena intuitiona sekä ymmärryksen ja järjen käsitteinä, mutta hänen projektiinsa ei kuulunut niiden alkuperän ja kehittymisen tutkiminen (ks. A19/B33-A41/B58). Yleisesti filosofian historiassa näitä sisäisiä tietokykyjä on kutsuttu sisäsyntyisiksi kyvyiksi ja niitä kannattavaa filosofista aatetta nativismiksi. Vaistosta käytyjen tieteellisten kiistojen osana oli vaiston käsittäminen sisäsyntyisenä kykynä, jota esimerkiksi Kuo (1921, 649) kritisoi. Bergsonin mukaan älykkyydellä ja vaistolla molemmilla on kuitenkin oma sisäsyntyisyytensä. Bergsonin mukaan vaisto toimii kuin se käsittäisi vain kategorisia arvostelmia, kun taas älykkyys toimii kuin se käsittäisi vain hypoteettisia arvostelmia. (Bergson 2013/1907, 149-50.)

Arvostelma voidaan nähdä tiedon yhtenä perusperiaatteena, sillä se liittyy yksilön tiedon arviointiin ja valintaan tai päätöksentekoon tämän tiedon pohjalta. Kant määrittelee arvostelmien ominaisuudet klassisesti: "Kategorinen arvostelma muodostaa materiaalin toisille [arvostelmille]. Kaikkien arvostelmien aines [on] joko käsitteet tai toinen arvostelma." (Kant 2005, 16:631.) Kognition aines palautuu siten aina kategoristen arvostelmien osatekijöihin eli käsitteisiin (A70/B95A74/B99; Kant 2005, 16:631, 17:645). ${ }^{17}$ Kategorinen arvostelma muodostaa väitelauseen yhdistämällä kaksi käsitteellistettyä asiaintilaa kuten "puissa 
on lehdet" ja "nyt on kesä" kopulan avulla. Hypoteettiset arvostelmat puolestaan tekevät väitelauseen yhdistämällä kaksi kategorista arvostelmaa ehdolliseksi väitelauseeksi: "jos puissa on lehdet, niin nyt on kesä". Kant ilmaisee asian selkeästi: "[l] ogiikka ei katso [hypoteettisen arvostelman] sisältöä [...] vaan pikemminkin vain sen suhteen muotoa" (Kant 2005, 16:638).

Kuten edellä totesin, kategorinen arvostelma muodostuu kahdesta käsitteestä, joita sitoo yhteen kopula. Näiden käsitteiden on viitattava todellisiin asiaintiloihin, jotta arvostelma olisi mielekäs. Hypoteettisella arvostelmalla ei ole tällaista vaatimusta: sen pätevyys riippuu ainoastaan loogisesta muodosta. Kategorisen arvostelman ongelmaksi muodostuu sen käsitteiden pätevyyden todistaminen. Jos sanon, että "puissa on lehdet", voin tarkistaa asian katsomalla ulos ikkunasta: puissa todella on lehdet. Tällä tavalla voin ostensiivisesti todistaa väitteeni pätevyyden. Mutta näin tehdessäni tiedän jo mitä etsin: tiedän mitä "puulla" ja "lehdellä" tarkoitetaan, eikä minussa herää sen suurempia tieto-opillisia huolia. Joku voisi todeta minulle, että havaitsemani puu ei ollutkaan puu vaan pahvikuva, jolloin havaitsen tehneeni hätiköidyn ostension epäonnistuneella tunnistamisella. Huoleni herää vasta sitten kun pohdin syitä, jotka ovat johtaneet minut tunnistamaan ja yleistämään käsitteitä. Miten olen päätynyt tilanteeseen, jossa voin helposti tunnistaa puita? Mistä voin tietää mitä puun käsite tarkoittaa? Joku voisi huomauttaa minulle, että puun käsite voidaan määritellä siinä esiintyvien ominaisuuksien luetteloinnilla eli käsitteen ekstensiolla. Tämä ei kuitenkaan auta huoleeni, sillä kaikki nämä ominaisuudet ovat vain toisia käsitteitä, joiden vastaava määrittely johtaa loputtomaan kierteeseen, jossa käsitteitä määritellään käsitteillä. Ostensiokaan ei auta tähän regressioon, sillä ennen kuin voin osoittaa väitteelleni esimerkkejä, minun on jo osattava tunnistaa kohteet, joihin viittaan.

Varhaismodernit filosofit olivat jo perillä näistä minua huolettavista vaaroista. Erityisesti rationalisteiksi kutsutut Descartes, Baruch Spinoza (1632-1677) ja G. W. Leibniz (1646-1716) pyrkivät ratkaisemaan tiedon varmuuden selventämällä primitiivisiä käsitteitä, jotka ovat niin varmoja ja tosia, ettei niitä tarvitse selittää, ja joista muut käsitteet voidaan johtaa. (ks. AT III, 665-666; Descartes 2015b, 151; ks. Flage \& Bonnen 1997, 867.) Leibnizin mukaan asia voidaan tietää sen itsensä kautta eli sisäisesti tai toisten asioiden kautta eli ulkoisesti (ks. Garrett 2019, 64). Spinoza ilmaisee asian näin: "Mitä ei voi käsittää toisen kautta, täytyy käsittää itsensä kautta"18 (Spinoza 1994, Iax2, ks. Iax5). Mitä tämä "käsittäminen" (concipere) mahtaa tarkoittaa? Arkisesti käsittäminen tarkoittaa jonkin asian ymmärtämistä tai tajuamista. Nämä ovat kuitenkin pelkkiä vertauskuvia jollekin sellaiselle kognitiiviselle prosessille, jota filosofit eivät ole käsitteellisesti kyenneet ilmaisemaan, vaan he ovat joutuneet joko käyttämään kielikuvia tai turvautumaan periaatteisiin. Esimerkiksi Kant voidaan nähdä periaatteeseen tukeutuvana filosofina, koska hän määritteli latinan sanan concipere käsitteiden avulla tapahtuvana ymmärryksenä, eikä hän syventynyt aiheen problematiikkaan tämän enempää (ks. Berg 2018, 8). Tosiasia kuitenkin on, että tämä käsittäminen, ymmärtäminen tai tajuaminen on juuri se syy tai tekijä, joka antaa todellisen merkityksen käsitteille, jotka toimivat niminä tai symboleina kognitiiviselle prosessille, jota kutsutaan ymmärrykseksi.

Kuten totesin, huoleni eivät ratkea käsitteiden ekstensiolla tai ostensiolla. Käsitteellisen merkityksen perustalla on oltava kognitiivinen prosessi, joka mahdollistaa asioiden todellisen ymmärtämisen. Toisin sanoen on oltava sellainen kognitiivinen kyky, minkä avulla ihminen luo tai oppii asioiden merkityksiä. Bergson selvästi pyrkii selittämään käsitteiden intension (compréhension) tällaisesta tulokulmasta (ks. Bergson 2013/1907, 150). Kuten näimme, vaisto ei kykene suhteuttamaan käsitteitä toisiinsa sääntöjen avulla, jotka kuuluvat älykkyyden ominaisluonteeseen, mutta se kykenee organisoimaan ajattelua. Bergsonin mukaan juuri vaisto tarjoaa perustan ymmärrykselle, joka mahdollistaa käsitteellisten symbolien käytön, jotta älykkyys voisi käytellä niitä suhteellisen järkeilynsä mukaisesti. Jos vaisto on välitöntä käsitystä asioista ja jos varhaismodernit rationalistit pyrkivät selventämään inhimillistä tietokykyä aloittamalla asioista, jotka voidaan käsittää 
vain niiden itsensä kautta, eikö Bergson tässäkin tapauksessa osallistu vanhojen filosofisten ongelmien uudelleen muotoilemiseen, kuten hän on niin selkeästi ilmoittanut tekevänsä pääteostensa ongelmanasetteluissa (ks. Bergson 2013/1889, vii; 2012/1896, 1-9)?

Tätä filosofisten ongelmien uudelleen muotoilua havainnollistaa filosofisen ajattelun kontrasti tai vastakohtaisuus Descartesin ja Bergsonin välillä. Järjen käyttöohjeissa (Regulae ad directionem ingenii) ja erityisesti sen yhdennessätoista säännössä Descartes väittää, että ihmisen älykkyyttä on mahdollista laajentaa tai voimistaa (amplificare) tuomalla yhteen toisiinsa kytkeytyviä käsityksiä, jotta tietoisuus voisi intuoida ne kuin ne olisivat yksi kokonaisuus. Näiden käsitysten erillinen intuointi samanaikaisella kognitiivisella ponnistuksella olisi inhimillisen ajattelun puitteissa mahdotonta. (AT X, 409; Descartes 2015a, 74-75.) Descartesin mukaan asianmukaisilla keinoilla inhimillinen ajattelu voi integroida käsittämänsä yksittäiset asiat kuin yhdeksi kokonaisuudeksi ja laajentaa kykyään kohteidensa välittömään intuointiin. Descartes kutsuu tällaista kykyä "päättelykyvyksi" (capacitate illationis; AT X, 407; Descartes 2015a, 73).

Bergson on ilmaissut tavoitteiltaan Descartesin "päättelykykyä" muistuttavan mutta sille lähes vastakkaisen ajattelutavan artikkelissaan "Älyllinen ponnistus" ("L'effort intellectuel", 1958). Lyhyesti sanottuna älyllinen ponnistus tarkoittaa Bergsonille ajattelun aineksen organisoivaa ponnistelua, joka eroaa älykkyyden formaalista päättelystä. Tämä aines on sitä, mitä voidaan käsitteellistää älykkyyden järkeilyn käyttöön. Siinä missä Descartesin päättelykyky tarkoittaa yksittäisten kognition kohteiden syntetisointia yhdellä kognitioaktilla suoritettavaksi, Bergsonille yksittäisiä käsitteitä ei syntetisoida: niiden avulla intuoidaan mielteiden organisoituminen, joka mahdollistaa myös uusien käsitteiden analyysin. Tällainen kognitio on Bergsonin mukaan "elollisen aktiivisuuden luonteenomainen tunnusmerkki" (caractéristique de l'activité vitale; Bergson 1958b, 184). Ymmärtämällä uudella tavalla tiedon muodostumisen biologiset lähtökohdat Bergson muotoilee Descartesin "päättelykykyä" muistuttavan ajatte- lutavan, joka on toimintaperiaatteeltaan suoranaisesti sen vastakohta: ajattelun yksiköitä ei enää syntetisoida yhteen, sillä nämä yksiköt eivät ole lähtökohta vaan tuotos. Ne ovat ei-käsitteellisen kognitiivisen aineksen käsitteellistyksiä. Ajattelun ykseydet ovat tietynlaisina kognitiivisina kokonaisuuksina jo olemassa, mutta niitä on sympatialla tai intuitiolla organisoitava. Hyvin organisoituneet kognitiiviset kokonaisuudet voidaan sitten muuttaa tai kääntää diskursiiviseksi eli käsitteelliseksi tiedoksi analyysin avulla.

Ilman käsitteitä ei olisi symboleita, joihin tukeutumalla älykkyys voisi järkeillä. Mutta ilman ymmärrystä siitä, mitä on käsitteellistetty tai mistä käsitteellistykset kumpuavat, käsitteellisen ajattelun formaalit toimintaperiaatteet olisivat hyödyttömiä. Bergsonin näkemys on tiivistetysti tämä: sellainen ei-käsitteellinen kognition muoto on pakko olla olemassa, joka ymmärtää tai ainakin pyrkii ymmärtämään asiat sellaisina kuin ne ovat, tai muutoin älykkyyden toiminnoilla ei olisi järkeiltävää materiaalia. Bergsonin mukaan "[o]n olemassa asioita, joita vain älykkyys kykenee etsimään, mutta joka ei yksinään osaa niitä koskaan löytää. Vain vaisto voi löytää nämä, mutta se ei koskaan etsi niitä." ${ }^{19}$ (Bergson 2013/1907, 152, kursiivi poistettu.) Filosofia yhdistää älykkyyden kyvyn etsiä asioita ja vaiston kyvyn löytää ne.

Älykkyyden ja vaiston yhteistoiminta tarjoaa filosofialle mahdollisuuden tiedon "integratiiviseen kokemukseen" (l'expérience intégrale; Bergson 2013/1932, 226-227, ks. 138; ks. 2013/1934, 263). Bergsonin integroinnin käsitys muistuttaa suuresti Descartesin käsitystä ajattelun integroinnista. Vaikka ranskan intégration kääntyy suomeksikin vierasperäiseksi matemaattiseksi käsitteeksi, sen kotoperäisenä vastineena toimii myös "sopeuttaminen". Filosofian tehtävänä on integroida eli sopeuttaa tietoa todellisuuden luonteenpiirteiden mukaan, joita käsitteellinen tieto ei sellaisenaan voi tavoittaa, mutta jonka mukaisesti sympatisoiva vaisto voi organisoida eikäsitteellisiä kognitiivisia kokonaisuuksia. Nämä kognitiiviset kokonaisuudet eivät myöskään näytä olevan älykkyyden toimintaperiaatteiden kuten sen kausaalimallien rajoittamia, koska ne ovat vaiston eivätkä älykkyyden tuotoksia. 


\section{Yhteenveto ja johtopäätökset}

Bergsonin filosofiassa elämällä on kaksoistehtävä: se toimii yhtäältä ennakkoehtona epistemologialle ja metafysiikalle ja toisaalta tutkimuskohteena, joka tarvitsee erityistä epistemologista ja metafyysistä lähestymistapaa. Tässä artikkelissa olen käsitellyt elämän kaksoistehtävää ja näiden tehtävien vastavuoroisuutta.

Ihmisen älykkyys ei voi sellaisenaan tavoittaa evoluution tuotosten luonteenpiirteitä, koska älykkyyden spatiaalinen luonne ja siitä seuraavat kognitiiviset toiminnot, kuten toisistaan erilliset mielteet ja niiden välille luodut mekanistiset ja finalistiset kausaalisuhteet, eivät ole yhteensopivia evolutiivisen kausaalisuuden kanssa (Bergson 2012/1896, 204; 2013/1907, 197). Älykkyyden toimintaperiaatteiden systematisoiminen tieteeksi on kuitenkin tehokas tapa kerätä tietoa ja tutkia todellisuuden ilmiöitä. Bergsonin mukaan tieteellinen tieto jakaakin tavanomaisen järkeilyn toimintaperiaatteen ja on sen systematisoitu muoto (Bergson 2013/1907, 29, 335-336). Sama ajatus on viimeisten vuosikymmenten aikana esiintynyt niin sanotussa kognitiivisessa tieteenteoriassa (ks. Giere 1997, 1-18; Hoyningen-Huene 2013, 187-196).

Filosofian tehtävä ei kuitenkaan rajaudu älykkyyden toimintaperiaatteiden systematisoimiseen. Kaikkeen elämään, elämiseen ja elämisestä kumpuaviin ilmiöihin liittyvien asioiden ymmärtämiseen tarvitaan vaistomaisen kognition kehittämistä, jonka myötä niitä tutkivat tieteet saavat ominaisen metafysiikkansa ja epistemologiansa. (Vrt. Bergson 2013/1932, 103.) Bergsonin mukaan filosofia saa evoluutiobiologista tutkimusta hyödyntämällä paremman käsityksen tietokykyjen luonteenpiirteiden kehittymisestä. Näiden luonteenpiirteiden kehityshistorian käsittäminen auttavat tunnistamaan ihmisen ajattelun ja tietokykyjen rajoitteita. Tietokykyjen rajoitteiden ymmärtäminen puolestaan selkeyttää eri tiedon luonteiden jäsentämistä, joka on ehto ymmärtää epistemologian metafyysistä perustaa. Metafysiikan ja epistemologian kehittymisen hyödyt päätyvät myös biologiseen tutkimukseen, koska eri tieteenalat ovat riippuvaisia tietyistä metafyysisistä ja epistemologisista oletuksista. Bergsonin mukaan erityisesti elämätieteiden riippuvuus meta- fysiikasta on ilmeinen (ks. Bergson 2013/1907, 17, 195-201, 203, 258).

Bergsonin filosofia on merkittävä esimerkki filosofian ja tieteen yhteisestä kehityksestä ja siitä, kuinka tieteellinen edistys voi tarjota sen tuloksista ammentavalle filosofille materiaalia perimmäisten filosofisten ongelmien uudenlaiseen muotoiluun. Kun tieteellisen tiedon ja filosofisen tiedon luonteenpiirteet on ymmärretty oikein, tiede ja filosofia kykenevät yhteistyössä inhimillisen kognition luonnollisten rajoitteiden ylittämiseen. Luonnolliset rajoitteet eivät ole kauttaaltaan ehdottomia rajoitteita, vaan ajattelun kehittyminen eli oppiminen mahdollistaa niiden ylittämisen. Ajattelun ponnistelulla, työllä ja tutkimisella filosofia voi saavuttaa sellaisen absoluuttisen tiedon mahdollisuuden, joka jäsentää epistemologian ja biologian välisen vastavuoroisuuden yhä täsmällisemmällä tavalla. Filosofian tehtäväksi tällaisessa työssä muodostuu vaistomaisen kognition kehittäminen älyllisen kognition rinnalla.

YTM LAURI MYLLYMAA on väitöskirjatutkija Jyväskylän yliopiston Filosofian ja yhteiskuntatieteiden laitoksella.

\section{VIITTEET}

1 "la théorie de la connaissance et la théorie de la vie nous paraissent inséparables l'une de l'autre"

2 Kaikki Bergson-suomennokset kirjoittajan, ellei toisin mainita.

3 "le problème de la connaissance ... ne fait qu'un avec le problème métaphysique, et que l'un et l'autre relèvent alors de l'expérience"

4 "ne peut pas [...] accepter la relation établie par le pur intellectualisme entre [...] la métaphysique et la science"

5 "We have no knowledge of any thing but Phenomena; and our knowledge of phenomena is relative, not absolute. We know not the essence, nor the real mode of production, of any fact, but only its relations to other facts in the way of succession or of similitude."

6 " [p]roof that our cognitions are not, and never can be, absolute, is obtainable by analyzing either the product of thought, or the process of thought" 
7 Noudatan Bergsonin ilmaisun élan vital suomentamisessa J. A. Hollon (1885-1967) käännösratkaisua "elämän hyöky". Pidän käännösratkaisua täsmällisenä ja se kaiken lisäksi esiintyy ensimmäisessä varsinaisessa Bergson-suomennoksessa, ks. Bergson (1958a).

8 Käännän ranskan sanan morale tässä asiayhteydessä käyttäytymiseksi, sillä sen alkuperäinen merkitys sisälsi ihmisen yksilölliseen ja sosiaaliseen käyttäytymiseen liittyvät aiheet - moraalisen käytöksen mukaan luettuna.

9 Lalanden mukaan elämän hyöky tarkoittaa yksilön elämänkaaren aikana havaittavaa tietynlaista kyvykkyyttä, joka on yksilönkehityksen alussa voimakkaimmillaan ja heikkenee vanhuutta kohti, kunnes lopulta ruumis kuolee ja hajoaa. Arnaud François'n mukaan Bergson hyödynsi elämän hyöyn ilmaisuvoimaa. Lalande asetti elämän hyöyn Spencerin näkemystä vastaan, jonka mukaan elävän luonnon lakina on kehittyä homogeenisyydestä kohti yhä suurempaa heterogeenisyyttä. Lalanden mukaan tilanne on päinvastainen: todellisuus suuntaa kohti täyttä hajaantumista ja elämää luonnehtii tämän hajaantumisen vastustaminen. (François 2013, 491-492.) Nykypäivän populaaritieteellinen näkemys todellisuudesta puoltaa Lalanden asetelmaa: maailmankaikkeus kokonaisuudessaan on nähtävästi suuntaamassa kohti hajaantumista eli "entropiaa" tai "lämpökuolemaa", mutta paikallisesti energia (jonka osatekijä tai esiintymismuoto näkyvän maailmankaikkeuden aine on) voi järjestyä hyvinkin monimutkaisesti. Nähdäkseni myös Bergson jakaa tämän Lalanden ja populaaritieteellisen näkemyksen. Bergsonin tavoitteisiin ei kuitenkaan kuulunut maailmankaikkeuden selittäminen, vaikka hän kutsuukin todellisuuden muodostuvan kahdesta vastakkaiseen suuntaan kulkevasta liikkeestä (ks. Bergson 2013/1907, 269-270).

10 "n'est nullement pour l'ornement du style, ce n'est pas davantage pour masquer par une image notre ignorance de la cause profonde [de l'évolution]"

11 "il n'y a pas d'image, empruntée au monde physique, qui puisse en donner plus approximativement l'idée"

12 Ks. Burkart ym. 2017, 3-4; Dehaene 2011, 228; Emery 2004, 1905-1906; Gärdenfors \& Lombard 2018; Haggard 2019, 17.14; Howard 2018, 124; Lewis \& Harmand 2016, 2; Lombard \& Gärdenfors 2017; Mix ym. 2010; Roth 2015, 1, 5-6; Wynn \& Coolidge 2016, 204-205.
13 "[t]outes les opérations de notre intelligence tendent à la géométrie"

14 Kattavammasta vaiston käsitteen historiasta ks. Blix (2016); Diamond (1974); Malkemus (2015).

15 "L'instinct qui anime l'Abeille se confond donc avec la force dont la cellule est animée, ou ne fait que la prolonger. Dans des cas extrêmes comme celui-ci, il coïncide avec le travail d'organisation."

16 "Nulle part je n'ai prétendu qu'il fallût "remplacer l'intelligence par une chose différente" ou lui préférer l'instinct. J'ai simplement essayé de montrer que, lorsqu'on quitte le domaine des objets mathématiques et physiques pour entrer dans celui de la vie et de la conscience, on doit faire appel à un certain sense de la vie qui tranche sur l'entendement pur, et qui a son origine dans la même poussée vitale que l'instinct, quoique l'instinct proprement dit soit tout autre chose. Ce sens de la vie n'est que la conscience s'approfondissant de plus en plus en cherchant, par une espèce de torsion sur elle-même, à se replacer dans la direction de la nature. C'est un certain genre d'expérience, aussi vieux que l'humanité, mais dont la philosophie est loin d'avoir obtenu tout ce qu'elle en pourrait tirer."

17 Toisesta kategoristen ja hypoteettisten arvostelmien merkittävästä historiallisesta teoreetikosta, ks. Boole (1854, 52-54).

18 "Id quod per aliud non potest concipi, per se concipi debet"

19 "[i]l y a des choses que l'intelligence seule est capable de chercher, mais que, par elle-même, elle ne trouvera jamais. Ces choses, l'instinct seul les trouverait; mais il ne les cherchera jamais.”

\section{KIRJALLISUUS}

AT III: Descartes, René (1996a) Oeuvres de Descartes III: Correspondance Janvier 1640 - Juin 1643. Toim. Charles Adam \& Paul Tannery. Vrin, Paris

AT VII: Descartes, René (1996b) Oeuvres de Descartes VII: Meditationes de prima philosophia. Toim. Charles Adam \& Paul Tannery. Vrin, Paris.

AT X: Descartes, René (1996c) Oeuvres de Descartes X: Physico-mathematica; Compendium musica; Regulae ad directionem ingenii; Recherche de la vérité; Supplément à la correspondance. Toim. Charles Adam \& Paul Tannery. Vrin, Paris

Barraclough, Timothy G. (2019) The Evolutionary Biology of Species. Oxford University Press, Oxford.

Beach, Frank A (1955) "The Descent of Instinct". Psychological Review 62:6, 401-410. 
Berg, Hein van den (2018) "A Blooming and Buzzing Confusion: Buffon, Reimarus, and Kant on Animal Cognition". Studies in History and Philosophy of Science Part C: Studies in History and Philosophy of Biological and Biomedical Sciences 72, 1-9.

Bergson, Henri (1908) "A propos de l' « Évolution de l'intelligence géométrique »". Revue de métaphysique et de morale 16:1, 28-33.

Bergson, Henri (1958a) Henkinen tarmo. Suomentanut J. A. Hollo. WSOY, Helsinki.

Bergson, Henri (1958b) "Älyllinen ponnistus". Suomentanut J. A. Hollo. Teoksessa Henri Bergson Henkinen tarmo. WSOY, Helsinki, 149-184.

Bergson, Henri (1972) Mélanges. Presses Universitaires de France, Paris.

Bergson, Henri (2012/1896) Matière et mémoire. Presses Universitaires de France, Paris.

Bergson, Henri (2013/1889) Essai sur les données immédiates de la conscience. Presses Universitaires de France, Paris.

Bergson, Henri (2013/1907) L'évolution créatrice. Presses Universitaires de France, Paris.

Bergson, Henri (2013/1932) Les deux sources de la morale et de la religion. Presses Universitaires de France, Paris.

Bergson, Henri (2013/1934) La pensée et le mouvant. Presses Universitaires de France, Paris.

Blix, Göran (2016) ”The Zoology of Mind: Instinct and Intelligence in Eighteenth-and Nineteenth-Century Natural History". L'Esprit créateur 56:4, 49-63.

Boole, George (1854) The Laws of Thought. Dover, New York.

Brigandt, Ingo (2005) "The Instinct Concept of the Early Konrad Lorenz". Journal of the History of Biology 38:3, 571-608.

Burkart, Judith M., Michèle N. Schubiger \& Carel P. van Schaik (2017) "The Evolution of General Intelligence". Behavioral and Brain Sciences 40, e195.

Carr, H. Wildon (1910) "III. Instinct and Intelligence". British Journal of Psychology 3:3, 230-236.

Comte, Auguste (1844) Discours sur l'esprit positif. CarilianGoeury et von Dalmont, Paris.

Condillac, Étienne Bonnot de (2014/1749) Essai sur l'origine des connaissances humaines. Vrin, Paris.

Darwin, Charles (2009/1871) The Descent of Man and Selection in Relation to Sex: Volume 1. Cambridge University Press, Cambridge.

Darwin, Charles (2016) Lajien Synty. Kääntänyt Pertti Ranta. 2. painos. Vastapaino, Tampere.

Dehaene, Stanislas (2011) The Number Sense: How the Mind Creates Mathematics. Oxford University Press, New York.

Descartes, René (2015a) Teokset I. Suom. Sami Jansson.
Gaudeamus, Helsinki.

Descartes, René (2015b) Teokset IV. Suom. Timo Kaitaro, Mikko Yrjönsuuri, Markku Roinila ja Tuomo Aho. Gaudeamus, Helsinki.

Dewey, John (1910) "Some Implications of AntiIntellectualism". The Journal of Philosophy, Psychology and Scientific Methods 7:18, 477-481.

Diamond, Solomon (1974) "Four Hundred Years of Instinct Controversy". Behavior Genetics 4:3, 237-252.

Emery, N. J. (2004) "The Mentality of Crows: Convergent Evolution of Intelligence in Corvids and Apes". Science 306:5703, 1903-1907.

Flage, Daniel E. \& Clarence A. Bonnen (1997) "Descartes on Causation". The Review of Metaphysics 50:4, 841-872.

François, Arnaud, toim. (2010a) L'Évolution Créatrice de Bergson. Vrin, Paris.

François, Arnaud (2010b) "L'évolution de la vie: mécanisme et finalité: commentaire". Teoksessa Arnaud François (toim.) L'évolution créatrice de Bergson. Vrin, Paris, 17-110.

François, Arnaud, toim. (2013) "Dossier critique". Teoksessa Henri Bergson L'évolution créatrice. Presses Universitaires de France, Paris, 373-693.

Garrett, Aaron (2019) "Spinoza". Teoksessa Stephen Gaukroger (toim.) Knowledge in Modern Philosophy. Bloomsbury Publishing, London, 63-77.

Gaukroger, Stephen, toim. (2019) Knowledge in Modern Philosophy. Bloomsbury Publishing, London.

Giere, Ronald N. (1997) Explaining Science: A Cognitive Approach. The University of Chicago Press, Chicago.

Gärdenfors, Peter \& Marlize Lombard (2018) "Causal Cognition, Force Dynamics and Early Hunting Technologies". Frontiers in Psychology 9:87.

Haggard, Patrick (2019) "The Neurocognitive Bases of Human Volition". Annual Review of Psychology 70:1, 9-28.

Hamilton, William (1860) Lectures on Metaphysics and Logic: Vol I: Metaphysics. Gould and Lincoln, Boston.

Howard, Marc W. (2018) "Memory as Perception of the Past: Compressed Time in Mind and Brain". Trends in Cognitive Sciences 22:2, 124-136.

Hoyningen-Huene, Paul (2013) Systematicity: The Nature of Science. Oxford University Press, New York.

Kant, Immanuel (2013/[1781/1787]) Puhtaan järjen kritiikki. Suom. Markus Nikkarla \& Kreeta Ranki. Gaudeamus, Helsinki.

Kant, Immanuel (2005) Notes and Fragments. Toim. Paul Guyer. Kään. Curtis Bowman, Paul Guyer, \& Frederick Rauscher. Cambridge University Press, Cambridge.

Kuo, Zing Yang (1921) "Giving up Instincts in Psychology". The Journal of Philosophy 18:24, 645-664. 
Lalande, André (1899) La dissolution opposée à l'évolution dans les sciences physiques et morales. Félix Alcan, Paris.

Landeweerd, Laurens (2021) Time, Life \& Memory: Bergson and Contemporary Science. Springer International Publishing, Cham.

Lee, Namhee, Lisa Mikesell, Anna Dina L. Joaquin, Andrea W. Mates \& John H. Schumann (2009) The Interactional Instinct: The Evolution and Acquisition of Language. Oxford University Press, Oxford.

Leslie, Martin P., Deborah E. Shelton \& Richard E. Michod (2017) "Generation Time and Fitness Tradeoffs during the Evolution of Multicellularity". Journal of Theoretical Biology 430, 92-102.

Lewis, Jason E. \& Sonia Harmand (2016) "An Earlier Origin for Stone Tool Making: Implications for Cognitive Evolution and the Transition to Homo". Philosophical Transactions of the Royal Society B: Biological Sciences 371:1698, 20150233.

Lévêque, Charles (1876) "L'instinct et la vie". Revue des Deux Mondes 16:2, 326-360.

Lombard, Marlize \& Peter Gärdenfors (2017) ”Tracking the Evolution of Causal Cognition in Humans". Journal of Anthropological Sciences 95, 219-234.

Malkemus, Samuel Arthur (2015) "Reclaiming Instinct: Exploring the Phylogenetic Unfolding of Animate Being”. Journal of Humanistic Psychology 55:1, 3-29.

Mill, John Stuart (1887) The Positive Philosophy of Auguste Comte. Henry Holt, New York.
Mix, Kelly S., Linda B. Smith \& Michael Gasser, toim. (2010) The Spatial Foundations of Language and Cognition. Oxford University Press, Oxford.

Richards, Robert J. (1974) "The Innate and the Learned: The Evolution of Konrad Lorenz's Theory of Instinct". Philosophy of the Social Sciences 4:2-3, 111-133.

Roff, D. A. \& D. J. Fairbairn (2007) "The Evolution of Trade-Offs: Where Are We?” Journal of Evolutionary Biology 20:2, 433-447.

Ronacher, Bernhard (2019) "Innate Releasing Mechanisms and Fixed Action Patterns: Basic Ethological Concepts as Drivers for Neuroethological Studies on Acoustic Communication in Orthoptera". Journal of Comparative Physiology A 205:1, 33-50.

Roth, G. (2015) "Convergent Evolution of Complex Brains and High Intelligence". Philosophical Transactions of the Royal Society B: Biological Sciences 370:20150049.

Scharfstein, Ben-Ami (1943) Roots of Bergson's Philosophy. Columbia University Press, New York.

Sinclair, Mark (2020) Bergson. Routledge, London.

Spencer, Herbert (2009/1862) First Principles. Cambridge University Press, Cambridge.

Spinoza, Baruch (1994) Etiikka. Suom. Vesa Oittinen. Gaudeamus, Helsinki.

Wynn, Thomas \& Frederick L. Coolidge (2016) "Archeological Insights into Hominin Cognitive Evolution". Evolutionary Anthropology: Issues, News, and Reviews 25:4, 200-213. 